\title{
Deoxyribonucleic Acid Base Compositions among Thermophilic Actinomycetes: the Occurrence of two Strains with Low GG Content
}

\author{
By R. CRAVERI, L. R. HILL, P. L. MANACHINI \\ AND L. G. SILVESTRI \\ Istituto di Microbiologia Agraria e Tecnica and Progetto Sistematica \\ Actinomiceti, Università Statale, Milan 4, Italy
}

(Received 17 June 1965)

\begin{abstract}
SUMMARY
Deoxyribonucleic acid (DNA) was extracted from two strains of Thermomonospora, two strains of Thermoactinopolyspora and one thermophilic strain of Streptosporangium. Base compositions were determined from 'melting-temperatures' (Tm) and, in two cases, from buoyant density. DNAs from both Thermoactinopolyspora strains and one Thermomonospora strain were of similar base composition to those previously reported for mesophilic actinomycetes. The other Thermomonospora strain and the Streptosporangium strain, both of which had higher temperature requirements and tolerance for growth, possessed DNA of lower GC content. These findings are discussed in relation to phylogeny, thermophily and the universality of the genetic code.
\end{abstract}

\section{INTRODUCTION}

Increasing importance is currently being given to the base compositions of deoxyribonucleic acids (DNA) as a useful adjunct to taxonomic studies (see Marmur, Falkow \& Mandel, 1963, for a recent review). Organisms of the Order Actinomycetales so far studied all possess DNA rich in guanine + cytosine (GC; Table 1). However, these data include no thermophilic actinomycetes. Here we report the base compositions of DNA from five thermophilic actinomycetes; three had \% GC values in the range of those given in Table 1 , but two possessed very different base ratios.

\section{METHODS}

Organisms. The strains of actinomycetes used in this study are listed in Table 2, together with their temperature requirements for growth. Morphological and physiological characterization of strain 5 (Thermomonospora sp.) as reported by Craveri \& Farina (1963) and Küster \& Locci (1963); those of strains 7 (Thermomonospora sp.) and 11 (a thermophilic Streptosporangium sp.) by Craveri \& Manachini (1965); those of strains 6 and 10 (both Thermoactinopolyspora sp.) by Craveri \& Pagani (1962). The genus Thermoactinopolyspora is considered to be closely related to the genus Thermopolyspora (Henssen, 1957).

Cultivation of organisms. Cultivation temperatures and media used for each strain are included in Table 2. All strains were grown in two stages on a 
Table 1. DNA base compositions within the genera of the Order Actinomycetales

\begin{tabular}{|c|c|c|c|}
\hline Genus & $\begin{array}{l}\text { Number of } \\
\text { species } \\
\text { examined }\end{array}$ & $\%$ GC range & References \\
\hline Mycobacterium & $\mathbf{3}$ & $66-72$ & 1,2 \\
\hline Nocardia & 4 & $68 \cdot 5-72$ & $1, \mathbf{3}, 4$ \\
\hline Streptomyces & 17 & $67-74$ & $1,3,4,5,6$ \\
\hline Micromonospora & 1 & 72 & $\mathbf{1}$ \\
\hline Actinoplanes & 1 & 73 & 4 \\
\hline Streptosporangium & $\mathbf{1}$ & $68 \cdot 5$ & 4 \\
\hline Streptoverticillium & 1 & 67 & 4 \\
\hline
\end{tabular}

1. Belozersky, Shugaeva \& Spirin, 1958.

2. Marmur et al. 1963.

3. Frontali et al. 1965 (buoyant density data; Tm data yielded values up to $78 \cdot 5 \%$ GC).

4. Jones \& Bradley, 1964 (Tm values only given in this paper; \% GC obtained by extrapolation in a manner similar to that of Silvestri \& Hill (1965), taking $E$. coli $=50 \%$ GC).

5. Marmur \& Doty, 1962.

6. Schildkraut et al. 1962.

reciprocal shaker. Mycelia were collected by centrifugation after 10-15 hr growth of second stage cultures, thus facilitating subsequent lysis (Frontali, Hill \& Silvestri, 1965).

Preparation of DNA specimens and Tm determinations. The procedure of Marmur (1961) was used, lysis of the mycelia being achieved with lysozyme followed by sodium lauryl sulphate. Final isopropanol DNA precipitates were dissolved in a solvent containing $0.01 \mathrm{M}-\mathrm{PO}_{4}{ }^{3-}+0 \cdot 001 \mathrm{M}$-EDTA, $\mathrm{pH} \mathrm{6.8}$, specific conductance $1 \cdot 345 \times 10^{-3}$ mho. Melting temperatures ( Tm) of DNA preparations were determined as described previously (Frontali et al. 1965) and \% GC values calculated according to the equation (modified from Marmur \& Doty, 1962, for the phosphate solvent used here): $\mathrm{Tm}=49 \cdot 3+0 \cdot 41(\mathrm{GC})$.

Determination of buoyant density $(\rho)$ values. $\mathrm{CsCl}$ buoyant density runs, lasting $20 \mathrm{hr}$ at 42,040 rev./min., were made in a Spinco model $\mathrm{E}$ analytical ultracentrifuge.

Table 2. Organisms, temperature requirements for growth and media used in the present work

\begin{tabular}{|c|c|c|c|c|c|c|}
\hline \multirow[b]{2}{*}{ No.* } & \multirow[b]{2}{*}{ Name† } & \multicolumn{3}{|c|}{ Temperature requirements } & \multirow{2}{*}{$\begin{array}{c}\text { Cult. } \\
\text { temp. } \\
\left(^{\circ}\right)\end{array}$} & \multirow[b]{2}{*}{$\begin{array}{c}\text { Culture } \\
\text { medium }\end{array}$} \\
\hline & & $37^{\circ}$ & $\begin{array}{c}\text { Opt. } \\
\text { temp. }\left({ }^{\circ}\right)\end{array}$ & $60^{\circ}$ & & \\
\hline 5 & Thermomonospora sp. & Growth & $45-50$ & No growth & 47 & Ter/1 Suppl. \\
\hline 7 & Thermomonospora sp. & No growth & $55-60$ & Growth & $\mathbf{5 4}$ & CPL \\
\hline 6 & Thermoactinopolyspora sp. & Growth & $45-50$ & No growth & 47 & Ter/1 Suppl. \\
\hline 10 & Thermoactinopolyspora sp. & Growth & 45-50 & No growth & 47 & Ter/1 Suppl. \\
\hline 11 & Streptosporangium sp. & No growth & $50-60$ & Growth & $\mathbf{5 2}$ & CPL \\
\hline
\end{tabular}

* Number in the collection held at the Istituto di Microbiologia Agraria e Tecnica.

+ According to Craveri \& Manachini (1965).

† Ter/1 Suppl.: Soya flour, 5 g.; unrefined maltose, 20 g.; yeast extract, 2 g.; peptone, 10 g.; tap water, 1 l.; pH 7.2.

CPL: Meat extract, 5 g.; yeast extract, 1 g.; distilled water, 1 1.; pH 7.2; supplemented with peptone (15 g.) for strain 7 or Tryptone (10 g.) for strain 11. 
Bacteriophage LP7 DNA was used as reference (1.740 g. $\left./ \mathrm{cm}^{3}\right) . \%$ GC was calculated from $\rho$ according to the equation: $\rho=1 \cdot 660+0.098(\mathrm{GC})$; (Schildkraut, Marmur \& Doty, 1962).

\section{RESULTS}

Tm values and calculated \% GC values of the DNA preparations are given in Table 3. The Tm values for both Thermoactinopolyspora sp. and for one Thermomonospora sp. (strain 5) fall within the range of $\mathrm{Tm}$ values, in the same solvent, previously reported for mesophilic streptomycetes $\left(79 \cdot 5-81 \cdot 5^{\circ}\right.$; Frontali et al. 1965). The other Thermomonospora sp. (strain 7) and the thermophilic Streptosporangium sp., both of which have higher temperature requirements and tolerance for growth than the three previous strains (Table 2), gave much lower Tm values.

Table 3. Tm, buoyant density and \% GC values of the DNA preparations

\begin{tabular}{rlcccc} 
No. & \multicolumn{1}{c}{$\begin{array}{c}\text { Name } \\
\text { 5 }\end{array}$} & Thermomonospora sp. & $\begin{array}{c}\text { Tm }\left(^{\circ}\right) \\
\text { from Tm }\end{array}$ & $\begin{array}{c}\rho \\
\text { g./cm. }\end{array}$ & $\begin{array}{c}\% \text { GC } \\
\text { from } \rho\end{array}$ \\
& & $\mathbf{7 9 \cdot 7 ^ { a }}$ & $\mathbf{7 3 \cdot 5}$ & - & - \\
7 & Thermomonospora sp. & $\mathbf{6 7 \cdot 3}$ & $\mathbf{4 3 \cdot 8}$ & $\mathbf{1 \cdot 7 0 3}$ & $\mathbf{4 4}$ \\
$\mathbf{6}$ & Thermoactinopolyspora sp. & $\mathbf{8 1 \cdot 0}$ & $\mathbf{7 7 \cdot 4}$ & - & - \\
10 & Thermoactinopolyspora sp. & $\mathbf{7 9 \cdot 7}$ & $\mathbf{7 4 \cdot 1}$ & - & - \\
11 & Streptosporangium sp. & $\mathbf{7 1 \cdot 1 ^ { b }}$ & $\mathbf{5 3 \cdot 7}$ & $\mathbf{1 . 7 0 8}$ & $\mathbf{4 9}$
\end{tabular}

Notes. Tm measured in $0.01 \mathrm{M}-\mathrm{PO}_{4}{ }^{3-}+0.001 \mathrm{M}-\mathrm{EDTA} ; a$ two determinations of the same DNA preparation; $b$ two DNA preparations. $\%$ GC values (col. 4) calculated from $\mathrm{Tm}=\mathbf{4 9 \cdot 3}+\mathbf{0 \cdot 4 1}$ (GC) (modified from Marmur \& Doty, 1962). $\rho$ values (col. 5) relative to bacteriophage LP 7. DNA $=1 \cdot 740 \mathrm{~g} . / \mathrm{cm} .{ }^{3} ; \%$ GC values (col. 6) calculated from $\rho=1 \cdot 660+0 \cdot 098(G C$; Schildkraut et al. 1962).

Since this result might have been due to the presence of an unusual base in the DNA, substituting for either adenine, thymine, guanine or cytosine, the two DNA preparations were further examined for their buoyant density in ultracentrifugation. These results are also included in Table 3. The buoyant density result for strain 7 confirms very closely the Tm result, whereas the difference of $4.7 \%$ GC between values calculated from Tm and from buoyant density for strain 11 is comparable with the systematic differences previously observed (Frontali et al. 1965). Both Tm and buoyant density values indicate that these two DNA preparations had unusually low GC contents relative to the three thermophilic actinomycetes and other members of Actinomycetales.

\section{DISCUSSION}

The present results raise a series of questions about the phylogeny of thermoactinomycetes and the universality of the genetic code. It is generally accepted that bacteria with widely different DNA base compositions are phylogenetically heterogeneous (Marmur et al. 1963; Sueoka, 1964: Silvestri \& Hill, 1964). According to this view, independent origin from the other actinomycetes would be postulated for the two thermophilic strains found here, from Tm and buoyant density measurements, to possess DNA of unusually low GC content, and they must consequently represent a striking case of morphological evolutionary convergence. We have 
recently described (Silvestri \& Hill, 1965) another situation of morphological resemblance between bacteria with very different DNA base compositions. Grampositive catalase-positive cocci had base ratios either in the range 31-36 \% GC or in the range 69-75\% GC. However, it was not difficult to imagine that morphological convergence had occurred and that the coccus form, the most simple of morphological forms, had been acquired independently by bacteria of diverse origin. Moreover, taxometric studies had also revealed two distinct groups (Hill, 1959; Hill et al. 1965), which corresponded to the base-composition groups. To propose that strains 7 and 11 are of independent origin from the other actinomycetes, and have come to resemble the latter through morphological convergence, meets with greater difficulty in view of the greater morphological differentiation of such organisms. Moreover, Weed (1963), Gause et al. (1964) and De Ley (1964) claim to have found induced mutants of other bacteria with DNA base ratios different (in some cases widely different) from their parental strains, thus suggesting the possibility that organisms with different DNA base ratios may have, nonetheless, a common origin.

From the morphological and physiological characters taken into consideration by taxonomists of actinomycetes, the two thermophilic strains of low GC content are similar to corresponding mesophilic strains (Craveri \& Manachini, 1965). This similarity, together with considerable differences in DNA base composition, is difficult to understand in terms of the universality of the genetic code, yet may find an explanation in terms of the degeneracy of the code. DNA base compositions of $70-75 \%$ GC on the one hand and $45-50 \%$ GC on the other, suggest that the proteins must also be very different. Thus it is surprising to find identical structures of such relative complexity as the fruiting bodies of actinomycetes. However, since the code is degenerate (Crick, 1963) the hypothesis could be advanced that, in the case of strains 7 and 11, more AT-rich triplets have been selected to code for the same or similar proteins than are coded for by synonymous, but GC-rich, triplets in other actinomycetes. This hypothesis could be tested experimentally by comparing, proteins from both these thermophilic actinomycetes and mesophilic strains.

Another interesting question is whether the low values of \% GC found for strains 7 and 11 are connected in some way with their greater thermophily (Table 2), for it is interesting to note that two other thermophilic bacterial species have also been reported to possess DNA base ratios similar to those found here for strains 7 and 11 (Bacillus stearothermophilus, 44\% GC, Marmur \& Doty, 1962; Clostridium nigrificans, two strains, $45 \%$ GC, Saunders, Campbell \& Postgate 1964).

We thank Professor F. Graziosi (Laboratorio Internazionale di Genetica e Biofisica, Naples) by whose courtesy the ultracentrifuge runs were made. Miss A. Uggè gave invaluable technical assistance. This work was partially supported by Assegnazione no. 04/130/5/1298 of the Consiglio Nazionale delle Ricerche. Publication no. 17 of the Progetto Sistematica Actinomiceti. 


\section{REFERENCES}

Belozersky, A. N., Shugatva, N. V. \& Spirin, A. S. (1958). Composition of desoxyribonucleic acids in different species of actinomycetes. Dokl. Akad. Nauk SSSR, 119, 330.

Craveri, R. \& Farina, G. (1963). Osservazioni al microscopio elettronico di Attinomiceti termofili. Atti XII ${ }^{\circ}$ Congr. Naz. Microbiol., Perugia, p. 266.

Craveri, R. \& Manachini, P. L. (1965). Caratteristiche e composizione in basi del DNA di alcuni attinomiceti termofili. Atti XIII ${ }^{\circ}$ Congr. Naz. Microbiol., Parma (in the Press).

Craveri, R. \& Pagani, H. (1962). Thermophilic microorganisms among the actinomycetes in the soil. Ann. Microbiol. 12, 115.

Crick, F. H. C. (1963). The recent excitement in the coding problem. Prog. Nucleic Acid Res. 1, 163.

DE LEY, J. (1964). Effect of mutation on DNA composition of some bacteria. Antonie van Leeurvenhoek, 30, 281.

Frontaxi, C., Hill, L. R. \& Silvestri, L. G. (1965). The base composition of deoxyribonucleic acids of streptomycetes. J. gen. Microbiol. 38, 243.

Gause, G. C., Loshrareva, N. P., ZBarsky, I. B. \& Gause, G. F. (1964). Deoxyribonucleic acid base composition in certain bacteria and their mutants with impaired respiration. Nature, Lond. 203, 598.

Henssen, A. (1957). Beiträge zur Morphologie und Systematik der thermophilen Actinomiceten. Arch. Mikrobiol. 26, 373.

Hill, L. R. (1959). The Adansonian classification of the staphylococi. J. gen. Microbiol. 20, 277.

Hill, L. R., Silvestri, L. G., Ihm, P., Farchi, G. \& Lanciani, P. (1965). Automatic classification of staphylococci by principal component analysis and a gradient method. J. Bact. 89, 1393.

Jones, L. A. \& Bradeyy, S. G. (1964). Phenetic classification of actinomycetes. Devel. ind. Microbiol. 5, 267.

KÜsTER, E. \& LocCI, R. (1963). Transfer of Thermoactinomyces viridis Schuurmans et al. 1956 to the genus Thermomonospora as Thermomonospora viridis (Schuurmans, Olson and San Clemente) comb. nov. Int. Bull. Bact. Nomencl. Taxon. 13, 213.

Marmur, J. (1961). A procedure for the isolation of deoxyribonucleic acid from microorganisms. J. mol. Biol. 3, 208.

Marmur, J. \& Doty, P. (1962). Determination of the base composition of deoxyribonucleic acid from its thermal denaturation temperature. J. mol. Biol. 5, 109.

Marmur, J., Falkow, S. \& Mandel, M. (1963). New approaches to bacterial taxonomy. Annu. Rev. Microbiol. 17, 329.

Saunders, G. F., Campbell, L. L. \& Postgate, J. R. (1964). Base composition of deoxyribonucleic acid of sulfate-reducing bacteria deduced from buoyant density measurements in cesium chloride. $J$. Bact. 87, 1073.

Schildkraut, C. L., Marmur, J. \& Doty, P. (1962). Determination of the base composition of deoxyribonucleic acid from its buoyant density in CsCl. J. mol. Biol. 4, 430.

Silvestri, L. G. \& Hill, L. R. (1964). Some problems of the taxometric approach. In Phenetic and Phylogenetic Classification. Systematics Assoc. Publ. no. 6, p. 87.

Siltestri, L. G. \& Hill, L. R. (1965). Agreement between DNA base composition and taxometric classification of Gram-positive cocci. J. Bact. 90, 136.

SueorA, N. (1964). In The Bacteria. Ed. by I. C. Gunsalus and R. Y. Stanier, vol. 5, p. 419. London and New York: Academic Press.

WEED, L. L. (1963). Effects of copper on Bacillus subtilis. J. Bact. 85, 1003. 